\title{
Pengaruh Model Discovery Learning Berbantuan Media Audio Visual dalam Setting Lesson Study terhadap Hasil Belajar IPA Mahasiswa PGSD Undiksha UPP Denpasar Tahun 2017
}

\author{
I Ketut Ardana ${ }^{1 *}$, I Nengah Suadnyana ${ }^{2}$ \\ 1,2 Jurusan Pendidikan Guru Sekolah Dasar, Universitas Pendidikan Ganesha
}

\section{A R T I C L E I N F O}

Article history:

Received 21 November

2017

Received in revised form

30 Desember 2017

Accepted 14 Januari 2018

Available online 20

Februari 2017

\section{Kata Kunci:}

Discovery learning, media audio visual, setting lesson study, hasil belajar IPA

Keywords:

discovery learning, media audio visual, setting lesson study, Science's learning outcomes

\begin{abstract}
A B S T R A K
Penelitian ini bertujuan untuk mengetahui perbedaan yang signifikan hasil belajar IPA yang dibelajarkan menggunakan model discovery learning berbantuan media audio visual dalam setting lesson study dan dibelajarkan menggunakan pembelajaran konvensional pada mahasiswa PGSD Undiksha UPP Denpasar tahun 2017. Penelitian ini merupakan penelitian eksperimen semu dengan desain penelitian nonequivalent control group design. Populasi dalam penelitian ini adalah seluruh mahasiswa PGSD berjumlah 182 mahasiswa dari 4 kelas. Sampel penelitian ditentukan dengan menggunakan teknik random sampling, sehingga diperoleh sampel kelas $\mathrm{J}$ sebanyak 45 mahasiswa dan kelas $\mathrm{H}$ sebanyak 46 mahasiswa. Data hasil belajar IPA dikumpulkan menggunakan tes objektif pilihan ganda biasa, kemudian dianalisis dengan uji-t.Hasil penelitian ini menunjukkan nilai rata-rata kelompok eksperimen yaitu 84,19 sedangkan rata-rata kelompok kontrol 70,00 . Dengan demikian dapat disimpulkan terdapat perbedaan yang signifikan hasil belajar IPA yang dibelajarkan menggunakan model discovery learning berbantuan media audio visual dalam setting lesson study dan dibelajarkan menggunakan pembelajaran konvensional pada mahasiswa PGSD Undiksha UPP Denpasar tahun 2017.
\end{abstract}

A B S T R A C T

This research was conducted to determine the significant diversification in science's learning outcome that are learned by using discovery learning model of audio-visual media in lesson study setting and it was learned using conventional learning on PGSD's student at Undiksha UPP Denpasar in 2017. This research is a quasi-experimental research with nonequivalent control group design. Population in this research is all student of PGSD amounted 182 students from 4 classes. The sample is determined by using random sampling technique, so that the sample of $\mathrm{J}$ class of 45 students and $\mathrm{H}$ class of 46 students was obtained. The data of science's learning outcomes were collected using the usual double choice objective test, then analyzed by t-test. The result of this study showed the average experimental group value is 84.19 while the control group average is 70.00 . Thus it can be concluded that there are significant differences in learning outcomes of science that are learned by using discovery learning model of audio-visual media in lesson study setting and learning using conventional learning in PGSD's student at Undiksha UPP Denpasar in 2017.

\footnotetext{
* Corresponding author.

E-mail addresses: Iketut.ardana@undiksha.ac.id (I Ketut Ardana)
} 


\section{Pendahuluan}

Pembelajaran yang diterapkan hendaknya berpusat pada mahasiswa yang bertujuan melatih mahasiswa agar kreatif dan inovatif. Berdasarkan paparan sebelumnya, ilmu pengetahuan alam (IPA) adalah ilmu yang mempelajari peristiwa-peristiwa yang terjadi dialam ini. Ilmu Pengetahuan Alam (IPA) berhubungan dengan cara mencari tahu tentang alam secara sistematis, sehingga IPA bukan hanya penguasaan kumpulan pengetahuan yang berupa fakta-fakta konsep-konsep, atau prinsip-prinsip saja tetap juga merupakan suatu proses penemuan. Menurut (Kadek \& Astiti, 2017) mata pelajaran IPA wajib diajarkan di sekolah dasar. IPA di sekolah dasar hendaknya membuka kesempatan untuk memupuk rasa ingin tahu siswa secara ilmiah Konsep IPA merupakan konsep yang masih terpadu ,karena belum dipisahkan secara tersendiri, seperti mata pelajaran kimia, biologi, fisika. Menurut (Prahasta \& Tegeh, 2016) mata pelajaran IPA merupakan mata pelajaran yang selama ini dianggap sulit oleh sebagian besar peserta didik, mulai dari jenjang sekolah dasar sampai sekolah menengah. Model discovery learning berbantuan media audio visual dalam setting lesson study adalah suatu model pembelajaran yang memberikan pengalaman belajar tidak hanya bersifat hafalan namun pengetahuan mereka peroleh sendiri dengan berperan aktif penemuannya sendiri dengan bantuan media penyaluran pesan melalui pendengaran (audio) dan pandangan (visual) serta lesson study yang dapat digunakan sebagai landasan pengembangan pembelajaran untuk meningkatkan professionalisme tenaga pendidik. Menurut (Md. Edi Andhika, I Wyn. Rinda Suardika, 2013) Media pembelajaran adalah segala sesuatu yang dapat digunakan untuk menyalurkan pesan dari pengirim ke penerima sehingga dapat merangsang pikiran, perasaan, perhatian, dan minat serta perhatian siswa sedemikian rupa sehingga proses belajar terjadi. Model discovery learning berbantuan media audio visual dalam setting lesson study membuat mahasiswa lebih aktif dan pembelajaran menjadi lebih bermakna. Menurut (Sudrajat, 2008) Lesson study bertujuan untuk memberikan imbas wawasan inovasi pembelajaran untuk dapat meningkatkan mutu/hasil belajar khususnya pendidikan kewarganegaraan di sekolah dasar. Hal itu karena model discovery learning berbantuan media audio visual menekankan kepada mahasiswa untuk membangun pengetahuannya sendiri dengan memberi permasalahan nyata yang memberikan pengalaman langsung kepada mahasiswa dalam pemecahannya. Media pembelajaran audio visual sebagai salah satu produk multimedia dewasa ini begitu populer, karena mampu mempresentasikan informasi secara lebih menarik kepada siswa (Pertiwi, Suditha, \& Wirya, 2013). Menurut media audio visual adalah media yang menyajikan materi dengan memanfaatkan indera pendengaran dan pengelihatan sebagai alat penyerapan informasi Sehingga memberikan kesempatan kepada mahasiswa untuk aktif membangun pengetahuannya sendiri. Media audio visual memiliki karakteristik, landasan teori, dan langkahlangkah pembelajaran yang berbeda. Maka hal ini diduga akan memberikan dampak atau pengaruh yang berbeda terhadap keterampilan menyimak siswa (Rosdiana, Kusmariyatni, Widiana, \& Pgsd, 2013). Menurut Rismawati (2013) model pembelajaran discovery learning, yaitu: (1) metode ini mampu membantu siswa untuk mengembangkan memperbanyak kesiapan serta penguasaan keterampilan dalam proses kognitif atau pengenalan siswa, (2) siswa memperoleh pengetahuan yang bersifat sangat pribadi atau individual sehingga dapat kokoh atau mendalam tertinggal dalam jiwa siswa tersebut, (3) dapat membangkitkan kegairahan belajar pada siswa.

Model discovery learning berbantuan media audio visual dalam setting lesson study membuat mahasiswa membangun makna belajar yang lebih kuat, kemudian diikuti dengan berfungsinya struktur kognitif mahasiswa secara lebih optimal sehingga berkesan lama dalam ingatan. Menurut (Tristiantari, 2017) lesson study merupakan model pembinaan profesi pendidik melalui pengkajian pembelajaran secara kolaboratif dan berkelanjutan berdasarkan prinsip-prinsip kolegalitas dan mutual learning untuk membangun learning community. Kegiatan awal yang dilakukan adalah merencanakan. Menurut (Jampel, 2016) lesson study merupakan model pembinaan profesi guru, yang dalam pelaksanaannya terdiri dari beberapa tahap yang harus dilakukan. Tiga tahapannya, yaitu Plan (merencanakan), Do (melaksanakan), dan See (merefleksi) yang berkelanjutan dan tak pernah berakhir (continous improvement). Dalam Lesson Study guru-guru merencanakan, mengajar, merefleksi bersama-sama dengan guru lain sejenis, dan sering dianggap sebagai "research lesson" (kaji pembelajaran). Melalui proses ini tim Lesson Study memusatkan perhatiannya kepada pemahaman belajar siswa (Suma, 2013). Menurut (Nugrahaeni, Redhana, \& Kartawan, 2017) model pembelajaran Discovery Learning merupakan suatu rangkaian kegiatan belajar yang melibatkan secara maksimal seluruh kemampuan siswa untuk mencari dan menyelidiki secara sistematis, kritis, logis, analitis sehingga mereka dapat merumuskan sendiri penemuannya. Dalam hal ini mahasiswa juga melakukan berbagai kegiatan seperti menghimpun informasi, membandingkan, mengategorikan, menganalisis, mengintegrasi, mere organisasikan bahan, serta membuat kesimpulan sebagai produk dari penemuan-penemuannya. Hal tersebut membuat pengetahuan yang didapat mahasiswa tidak berupa hapalan semata tetapi pengetahuan yang bermakna. 
(Putra, Wirawan, \& Pradnyana, 2017) Model pembelajaran discovery learning yang bertujuan untuk membuat peserta didik aktif, dan mandiri dalam proses belajarnya, bertanggung jawab dan berinisiatif untuk mengenali kebutuhan belajarnya, menemukan sumber-sumber informasi, untuk dapat menjawab kebutuhannya, membangun serta mempresentasikan pengetahuannya berdasarkan kebutuhan serta sumber-sumber yang ditemukan

Berdasarkan uraian tersebut dalam penelitian ini yaitu, terdapat perbedaan yang signifikan hasil belajar IPA kelompok mahasiswa yang dibelajarkan melalui Model discovery learning berbantuan media audio visual dalam setting lesson study dengan yang dibelajarkan melalui pembelajaran konvensional mahasiswa PGSD semester II Undiksha UPP Denpasar Tahun 2017.

\section{Metode}

Penelitian ini dilaksanakan pada mahasiswa PGSD semester 2 Undiksha UPP Denpasar. Jenis penelitian yang digunakan adakah penelitian "eksperimen".

Agung (2011:23) menyatakan bahwa "Penelitian eksperimen merupakan penelitian yang bertujuan untuk menguji keefektifan suatu teori/konsep/model dengan cara menerapkan (treatment) pada suatu kelompok subjek penelitian yang menggunakan kelompok pembanding yang biasa disebut kelompok kontrol". Desain eksperimen semu yang digunakan dalam penelitian ini adalah Nonequivalent Control Group Design.

Prates diberikan untuk kelompok kontrol dan kelompok eksperimen. Setelah itu peneliti memberikan perlakuan, yaitu dengan memberikan model sains teknologi masyarakat kepada kelompok eksperimen dan memberikan pembelajaran pendekatan saintifik kepada kelompok kontrol. Kemudian setelah diberikan perlakuan, dilakukan pasca tes untuk mengetahui penguasaan kompetensi pengetahuan.

"Pemberian prates biasanya digunakan untuk mengukur equivalensi atau penyetaraan kelompok" (Dantes, 2012: 97). Dalam penelitian ini dapat digunakan prates untuk penyetaraan kelompok. Teknik yang digunakan dalam penyetaraan kelompok adalah dengan menggunakan uji t.

Populasi dari penelitian ini adalah seluruh mahasiswa PGSD semester II Undiksha UPP Denpasar, yang terdiri dari 4 kelas. Dalam suatu penelitian tidak dimungkinkan mempelajari semua yang ada dalam populasi, misalnya karena keterbatasan dana, tenaga, dan waktu, maka dapat digunakan sampel yang diambil dari populasi itu. "Sampel adalah bagian dari jumlah dan karakteristik yang dimiliki oleh populasi tersebut" (Sugiyono, 2014:118). Dari pengertian tersebut memberi gambaran bahwa sampel mewakili populasi untuk dijadikan sebagai sumber data penelitian. Penggunaan sampel bertujuan untuk menghemat waktu, tenaga, dan biaya dalam melakukan penelitian.

Teknik yang digunakan untuk mengambil sampel dari populasi disebut "teknik sampling” (Agung, 2011:47). Teknik pengambilan sampel pada penelitian ini adalah Simple Random Sampling yang dirandom kelasnya, sehingga setiap kelas mendapatkan peluang yang sama untuk menjadi sampel penelitian. Pemilihan sampel penelitian ini tidak dilakukannya pengacakan individu melainkan hanya pengacakan kelas. Hal ini disebabkan karena tidak bisa mengubah kelas yang telah terbentuk sebelumnya. Kelas dipilih sebagaimana telah terbentuk tanpa adanya campur tangan siapapun dan tidak dilakukannya pengacakan individu, kemungkinan pengaruh-pengaruh dari keadaan mahasiswa mengetahui dirinya dilibatkan dalam eksperimen dapat dikurangi sehingga penelitian ini benar-benar menggambarkan pengaruh perlakuan yang diberikan.

Berdasarkan hasil uji homogenitas didapat Fhitung $=1,64$ sedangkan dari tabel harga Ftabel untuk $\alpha=5 \%$ dengan derajat kebebasan $(45,44)$ diperoleh harga Ftabel $=1,66$. Ternyata Fhitung kurang dari atau sama dengan Ftabel, yaitu 1,64 < 1,66 sehingga dapat disimpulkan data berasal dari populasi yang homogen. Karena data berdistribusi normal dan homogen, maka dilanjutkan dengan melakukan uji kesetaraan menggunakan uji-t. Dari hasil pengujian, kedua kelompok memiliki thitung kurang dari atau sama dengan ttabel, yang artinya tidak memiliki perbedaan yang signifikan atau setara.

Penelitian ini merupakan penelitian eksperimen semu dengan desain nonequivalent control group design yang melibatkan dua kelompok yaitu satu kelompok eksperimen dan satu kelompok kontrol. Kelompok eksperimen dibelajarkan menggunakan model discovry learning berbantuan media audio visual dalam setting lesson study dan kelompok kontrol dibelajarkan menggunakan pembelajaran konvensional. Pemberian treatment dilaksanakan sebanyak 6 kali pertemuan baik di kelompok eksperimen maupun kelompok kontrol. Data hasil belajar IPA pada penelitian ini diperoleh dengan motode tes.

Data dalam penelitian ini dikelompokkan menjadi dua, yaitu kelompok data hasil belajar mahasiswa di kelompok eksperimen yang dibelajarkan menggunakan model discovry learning berbantuan media audio visual dalam setting lesson study dan data hasil belajar mahsiswa di kelompok 
kontrol yang dibelajarkan menggunakan pembelajaran konvensional. Namun yang dianalisis adalah nilai hasil belajar IPA saja.

Uji hipotesis dilakukan untuk menguji hipotesis penelitian yang diajukan. Hipotesis nol (H0) menyatakan bahwa tidak terdapat perbedaan yang signifikan hasil belajar IPA yang dibelajarkan menggunakan model discovey learning berbantuan media audio visual dalam setting lesson study dan yang dibelajarkan menggunakan pembelajaran konvensional pada mahasiswa PGSD Undiksha UPP Denpasar Tahun 2017. Sedangkan hipotesis alternatif (Ha) menyatakan bahwa terdapat perbedaan yang signifikan hasil belajar IPA yang dibelajarkan menggunakan model discovey learning berbantuan media audio visual dalam setting lesson study dan yang dibelajarkan menggunakan pembelajaran konvensional pada mahasiswa PGSD Undiksha UPP Denpasar Tahun 2017.

Hipotesis yang diajukan diuji menggunakan uji-t. Uji-t adalah teknik statistik parametrik yang digunakan untuk membandingkn 1 variabel bebas dan 1 variabel terikat. Hasil uji prasyarat yang telah dilaksanakan menunjukkan bahwa uji hipotesis dengan uji-t dapat dilakukan karena data telah berdistribusi normal dan homogen. Uji hipotesis dilakukan pada taraf signifikansi 5\% dengan kaidah hipotesis $\mathrm{HO}$ ditolak jika thitung lebih dari ttabel. Dan H0 diterima jika thitung kurang dari atau sama dengan ttabel. Berdasarkan hasil analisis uji-t dari data hasil belajar IPA mahasiswa diperoleh hasil sebagai berikut.

Tabel 1. Hasil analisis uji-t

\begin{tabular}{lllll}
\hline No. & Sampel & thitung & tabel & Keterangan \\
\hline 1. & Kelompok Eksperimen & 6,662 & 2,000 & Signifikan \\
2. & Kelompok Kontrol & & & \\
\hline
\end{tabular}

Berdasarkan hasil analisis data diperoleh thitung sebesar 6,662. Harga tersebut kemudian dibandingkan dengan harga ttabel. Harga ttabel diperoleh dari tabel nilai-nilai dalam distribusi t dengan derajat kebebasan ( $\mathrm{dk}=45+46-2=89$ ), pada taraf signifikansi 5\%. Berdasarkan tabel nilai-nilai dalam distribusi t diperoleh harga ttabel sebesar 2,000. Karena thitung lebih dari ttabel $(6,662>2,000)$ maka HO ditolak atau Ha diterima. Hal ini berarti terdapat perbedaan yang signifikan hasil belajar IPA yang dibelajarkan menggunakan model discovey learning berbantuan media audio visual dalam setting lesson study dan yang dibelajarkan menggunakan pembelajaran konvensional pada mahasiswa PGSD Undiksha UPP Denpasar Tahun 2017.

Mahasiswa kelas J merupakan kelas yang ditetapkan sebagai kelompok eksperimen. Mahasiswa kelas J di kelompok eksperimen ini terdiri atas 45 mahasiswa. Sedangkan mahasiswa kelas H merupakan kelas yang ditetapkan sebagai kelompok kontrol. Mahasiswa di kelompok kontrol terdiri dari 46 mahasiswa. Mahasiswa pada kelompok eskperimen diberikan treatment berupa pembelajaran dengan model discovery learning berbantuan media audio visual dalam setting lesson study. Sedangkan mahasiswa pada kelompok kontrol diberikan treatment berupa pembelajaran dengan pembelajaran konvensional. Sebelum diberikan perlakuan, kemampuan awal yang dimiliki mahasiswa yang menjadi sampel setara, hal ini menunjukkan bahwa perbedaan hasil belajar yang ada setelah diberikan perlakuan adalah pengaruh dari perbedaan perlakuan (treatment) yang diberikan pada sampel penelitian. Perlakuan diberikan sebanyak 6 kali pada masing-masing kelas dan setelah diberikan perlakuan dilanjutkan dengan pemberian pasca tes.

Tes yang digunakan dalam pemberian pasca tes adalah tes hasil belajar IPA pilihan ganda biasa. Data yang diperoleh dalam penelitian ini menunjukkan adanya perbedaan hasil belajar IPA yang dibelajarkan menggunakan model discovery learning berbantuan media audio visual dalam setting lesson study dan yang dibelajarkan menggunakan pembelajaran konvensional pada mahasiswa PGSD Undiksha UPP Denpasar Tahun 2017. Perbedaan ini ditunjukkan oleh nilai rata-rata hasil belajar IPA mahasiswa, pada kelas eksperimen memiliki nilai rata-rata 84,19 dan kelas kontrol memiliki nilai rata-rata 70,00. Hasil perhitungan analisis data juga mempertegas perbedaan hasil belajar IPA mahasiswa. Derajat kebebasan $(\mathrm{dk}=45+46-2=89)$, pada taraf signifikansi 5\% diperoleh harga ttabel sebesar 2,000, sedangkan berdasarkan hasil pengujian hipotesis nilai thitung $=6,662$. Karena thitung lebih dari ttabel $(6,662>2,000)$ maka H0 ditolak atau Ha diterima. Jadi terdapat perbedaan yang signifikan hasil belajar IPA yang dibelajarkan menggunakan model discovery learning berbantuan media audio visual dalam setting lesson study dan yang dibelajarkan menggunakan pembelajaran konvensional pada mahasiswa PGSD Undiksha UPP Denpasar Tahun 2017. 


\section{Hasil dan pembahasan}

Pembelajaran di kelompok eksperimen, yaitu dibelajarkan dengan model discovery learning berbantuan media audio visual dalam setting lesson study ternyata lebih unggul. Hal ini terjadi karena model discovery learning berbantuan media audio visual dalam setting lesson study mampu menciptakan suasana belajar yang aktif dan menyenangkan. Model discovery learning berbantuan media audio visual dalam setting lesson study memberikan kesempatan pada siswa untuk lebih aktif mencari informasi dan menggali pengetahuan untuk memecahkan suatau masalah. Dalam proses pembelajaran siswa diajak untuk mencari dan menemukan informasi. Mahasiswa diminta untuk mencari informasi sebanyakbanyaknya, kemudian mahasiswa diminta untuk menganalisis permasalahan di masyarakat yang telah dikemukakan pada awal pembelajaran. Model pembelajaran ini model discovery learning berbantuan media audio visual dalam setting lesson study membuat mahasiswa menjadi aktif dalam proses interaksi, baik interaksi antar mahasiswa maupun dengan dosen. Mahasiswa juga merasa senang ketika diajak untuk melakukan praktikum dan mengamati lingkungan sekitarnya. Jadi, mahasiswa dapat secara nyata memperoleh pengetahuannya. Berbeda dengan pembelajaran di kelompok kontrol yang dibelajarkan menggunakan pembelajaran konvensional. Pembelajaran konvensinal yang diterapkan tersebut cenderung menyebabkan mahasiswa menjadi kurang aktif dan masih terdapat mahasiswa yang kurang terlibat dalam proses pembelajaran, sehingga menyebabkan hasil belajar mahasiswa kurang optimal. Dalam penerapan pembelajaran konvensional pada proses pembelajaran, kurang ada inovasi yang dapat membuat mahasiswa aktif dan senang dalam mengikuti proses pembelajaran. Mahasiswa hanya belajar di dalam kelas, dan dosen cenderung masih menggunakan metode ceramah sehingga mahasiswa menjadi bosan. Hal ini mendukung hipotesis yang menyatakan bahwa terdapat perbedaan yang signifikan hasil belajar IPA yang dibelajarkan menggunakan Model discovery learning berbantuan media audio visual dalam setting lesson study dan yang dibelajarkan menggunakan pembelajaran konvensional pada mahasiswa PGSD Undiksha UPP Denpasar Tahun 2017.

\section{Simpulan dan saran}

Berdasarkan hasil analisis data diperoleh thitung sebesar 6,662. Harga tersebut kemudian dibandingkan dengan harga ttabel. Harga ttabel diperoleh dari tabel nilai-nilai dalam distribusi $t$ dengan derajat kebebasan $(\mathrm{dk}=45+46-2=89)$, pada taraf signifikansi 5\%. Berdasarkan tabel nilai-nilai dalam distribusi t diperoleh harga ttabel sebesar 2,000. Karena thitung lebih dari ttabel $(6,662>2,000)$ maka HO ditolak atau Ha diterima. Hal ini berarti terdapat perbedaan yang signifikan hasil belajar IPA yang dibelajarkan menggunakan model discovey learning berbantuan media audio visual dalam setting lesson study dan yang dibelajarkan menggunakan pembelajaran konvensional pada mahasiswa PGSD Undiksha UPP Denpasar Tahun 2017

\section{Daftar Rujukan}

Agung, A. A. Gede. 2011. Pengantar Evaluasi Pendidikan. Singaraja: FIP Undiksha.

Arifin, Zainal. 2009. Evaluasi Pembelajaran. Bandung: PT. Remaja Rosdakarya.

Arikunto, Suharsimi. 2003. Dasar-dasar Evaluasi Pendidikan. Jakarta: Bumi Aksara.

Arsyad, Azhar. 2011. Media Pembelajaran. Jakarta : PT Rajagrafindo Persada

Aunurrahman. 2013. Belajar dan Pembelajaran. Bandung: Alfabeta.

Dantes, Nyoman. 2012. Metode Penelitian. Yogyakarta: Andi.

Departemen Pendidikan Nasional. 2008. Kamus Bahasa Indonesia. Jakarta: Pusat Bahasa.

Hamalik, Oemar. 2001. Proses Belajar Mengajar. Jakarta: Bumi Aksara.

Husamah. 2013. Outdoor Learning. Jakarta: Prestasi Pustakaraya. 
Jasdilla. 2017. Hasil Belajar dan Pembelajaran Kooperatif Tipe TPS. Jurnal Pendidikan Indonesia Vol. 6, No.1, April 2017

Komara, Endang. 2014. Belajar dan Pembelajaran Interaktif. Bandung: PT Refika Aditama.

Kosasih. 2014. Strategi Belajar Dan Pembelajaran. Bandung : Yrama Widya

Samatowa, Usman. 2016. Pembelajaran IPA di Sekolah Dasar. Jakarta: PT Indeks.

Sanjaya, Wina. 2013. Penelitian Pendidikan. Jakarta: Prenada Media Group.

Sugiyono. 2014. Metode Penelitian Pendidikan Pendekatan Kuantitatif. Jakarta: Alfabeta.

Sugiyono. 2016. Statistik untuk Penelitian. Bandung: Alfabeta

Sukardi. 2003. Metodologi Penelitian Pendidikan. Jakarta: PT Bumi Aksara.

Sukiman. 2012. Pengembangan Media Pembelajaran. Yogyakarta: Pedagogia (PT Pustaka Insan Madani).

Susanto, Ahmad. 2013. Teori Belajar dan Pembelajaran Di Sekolah Dasar. Jakarta: Kencana.

Setyawan, Denny. 2009. Komputer dan Media Pembelajaran. Jakarta: Universitas Terbuka

Setyosari, Punaji. 2015. Metode Penelitian Pendidikan \& Pengembangan. Jakarta: Prenadamedia Group

Uno, Prof. Dr. Hamzah B. 2014. Assessment Pembelajaran. Jakarta: PT Bumi Aksara.

Yusuf, Muri. 2015. Asesmen dan Evaluasi Pendidikan. Jakarta: Prenadamedia Gru

Jampel. (2016). Pelatihan pengembangan asesmen autentik dalam implementasi kurikulum 2013 di sekolah dasar berbasis lesson study bagi guru-guru SD, 5(1), 10-19.

Kadek, D., \& Astiti, S. (2017). Penerapan Metode Pembelajaran Jigsaw Sebagai Upaya Meningkatkan Hasil Belajar Ipa Pada Siswa Kelas Iv Sd. Jurnal Ilmiah Sekolah Dasar. Universitas Pendidikan Ganesha, $1(2), 30-41$.

Md. Edi Andhika, I Wyn. Rinda Suardika, I. K. N. W. (2013). Pengaruh Model Pembelajaran Kooperatif Tipe Inside Outside Circle Berbasis Media Audio Visual Animation Terhadap Hasil Belajar IPS. Pgsd.

Nugrahaeni, A., Redhana, I. W., \& Kartawan, I. M. A. (2017). Penerapan Model Pembelajaran Discovery Learning Untuk Meningkatkan Kemampuan Berpikir Kritis Dan Hasil Belajar Kimia. Jurnal Pendidikan Kimia Indonesia, 1(1), 23-29.

Pertiwi, M. T., Suditha, W. R., \& Wirya, I. N. (2013). Pengembangan Media Pembelajaran Audio Visual Dalam Mata Pelajaran Pendidikan Kewarganegaraan Pada Siswa Kelas Viii Semester Ii Tahun Pelajaran 2012 / 2013 Smpn 2 Kerambitan Tabanan Jurusan Teknologi Pendidikan , Fakultas Ilmu Pendidikan Universitas Pendid.

Prahasta, K. A., \& Tegeh, I. M. (2016). Hasil Belajar Ipa Pada Siswa Kelas V Sd, (11), 70-79.

Putra, K. W. B., Wirawan, I. M. A., \& Pradnyana, G. A. (2017). Pengembangan E-Modul Berbasis Model Pembelajaran Discovery Learning Pada Mata Pelajaran "Sistem Komputer" Untuk Siswa Kelas X Multimedia Smk Negeri 3 Singaraja. Jurnal Pendidikan Teknologi Dan Kejuruan, 14(1), 40-49. https://doi.org/10.23887/jptk.v14i1.9880

Rosdiana, E., Kusmariyatni, N. N., Widiana, I. W., \& Pgsd, J. (2013). Pengaruh model pembelajaran kooperatif tipe paired storytelling berbantuan media audio visual terhadap keterampilan menyimak bahasa indonesia siswa kelas V SD. 
Sudrajat, A. (2008). Lesson Study untuk meningkatkan hasil dan pembelajaran, 104-113.

Suma. (2013). Implementasi lesson study sebagai upaya pembinaan profesionalisme guru mipa sma di kabupaten bangli, (2003), 38-45.

Tristiantari, K. D. (2017). Model Pembelajaran Cooperatif Integrated Reading Composition Berpola Lesson Study Meningkatkan Keterampilan Membaca dan Menulis. Pendidikan Indonesia, 5(2), 912-920. https://doi.org/10.23887/jpi-undiksha.v5i2.8493 